\title{
Varicella Zoster Infection
}

National Cancer Institute

\section{Source}

National Cancer Institute. Varicella Zoster Infection. NCI Thesaurus. Code C96407.

A highly contagious viral infection caused by the varicella zoster virus. Clinically, it may be manifested as shingles or chicken pox. 